Religion and Gender, vol. 2, no. 2 (2012), pp.

207-230

WWW.religionandgender.org

URN:NBN:NL:UI:10-1-101601

ISSN: $1878-5417$

Publisher: Igitur Publishing (Utrecht)

Copyright: this work is licensed under a Creative

Commons Attribution License (3.0)

\title{
Masculinities and Religion in Kaduna, Nigeria: A Struggle for Continuity at a Time of Change
}

\author{
COLETTE HARRIS
}

\begin{abstract}
This paper addresses coping strategies used by men in Kaduna to ward off chaos resulting from economic instability, situating them within the global context and national policies on gender and religion. They include upholding a set of gender norms in which adult masculinity's most crucial traits are control over women and children, and breadwinning. These norms were introduced into Nigeria under colonialism and through Islam and Christianity, yet today they are considered to represent local traditions. Religion is also important for coping strategies, especially the newer Pentecostal churches and reformist mosques, characterized by emphasis on literalist interpretations of the scriptures and notions of male superiority. Poor men have particularly welcomed the levels of certainty, moral and material support they provide as well as the legitimization of their gender power positions, especially those struggling to perform appropriate masculinity, while at the same time these establishments have facilitated sectarian violence.
\end{abstract}

\section{Keywords}

Nigeria, gender, masculinities, Christianity, Islam, sectarian violence 


\section{Author affiliation}

Colette Harris is a political scientist and Senior Lecturer in conflict, governance and development in the School of International Development, University of East Anglia, with research interests in the intersection of power, gender identities, violent conflict and religion. She also designs community-based education projects and studies their impact. She has carried out research in all three continents of the global South, mainly in post-conflict settings, with special emphasis on West and East Africa and Central Asia. Email: colette.harris@uea.ac.uk

\section{Introduction $^{1}$}

This paper addresses the issue of how men in Kaduna in northern Nigeria have been affected by global processes of change, and their coping strategies. In so doing it looks at the interconnections between colonialism, religion, globalizing capitalism, and the Nigerian state in relation to the performance of masculinities among the male inhabitants of the city.

The importance placed on gender by the aforementioned institutions can be seen by the attention they pay to it. Feminist scholars have shown how crucial gender, particularly masculinity, is to all aspects of politics, despite its largely being ignored by mainstream political scientists. ${ }^{2}$ R.W. Connell has further posited the notion that we are all embedded in a 'global gender order' that links the local and the transnational in multiple, often contradictory and always complex, ways to globalizing capitalism at the centre. ${ }^{3}$

The word 'order' is crucial here, implying as it does the opposite of chaos, and Connell suggests that gender bears similar connotations in that it too is intimately related to attempts to organize society. According to Shmuel Eisenstadt, religion lends itself to the same purposes, ${ }^{4}$ making it a

1 I wish to thank the editors of this special issue, the journal editors, the anonymous reviewer, and also Ben Jones, Lee Marsden, and Paolo Possiedi for their comments on earlier versions of this paper. I extend a particular thanks to Robert Morrell for his most useful remarks on the masculinities sections.

2 Cynthia Enloe, Globalization and Militarism, Lanham, MD: Rowman \& Littlefield 2007; Kimberly Hutchings, 'Cognitive Short Cuts' in Jane Parpart and Marysia Zalewski (eds.), Rethinking the Man Question: Sex, Gender and Violence in International Relations, London: Zed 2008, 23-46. Colette Harris, 'State Business: Gender, Sex and Marriage in Tajikistan' in Central Asian Survey, 30:1 (2011), 97-111.

3 R.W. Connell, 'Globalization, Imperialism, and Masculinities' in Michael S. Kimmel, Jeff Hearn, and R.W. Connell (eds.), Handbook of Studies on Men and Masculinities, Thousand Oaks, CA: Sage Publications 2005, 71-89.

4 Shmuel Eisenstadt, 'The Construction of Collective Identities and the Continual Reconstruction of Primordiality' in Sinisa Maleseviç and Mark Haugaard (eds.), Making 
useful bedfellow for gender, as we shall see. Moreover, religion and gender are symbiotically linked through normative notions of social practices.

This paper explores how these two institutions are deployed by men reacting to the crumbling of the social order under economic stresses as they seek to find their feet in the face of change. I argue that they use religion and particularly membership of newer churches and mosques to support them in making sense of the unstable situations in which they live, as well as in preserving their masculine power position within the family, while some of these religious institutions also facilitate participation in the sectarian violence that has come to dominate the scene in Kaduna today. Meanwhile, all of this is sustained by the position of the Nigerian state, embedded as it is in the (neoliberally organized) global political economy.

\section{Methodology}

The data this paper is based on were collected between 2007 and 2011 in the course of a series of research projects under the auspices respectively of the Citizenship Development Research Centre funded by the UK's Department for International Development and the British Research Councils' Religion and Society Programme. ${ }^{5}$ The main fieldwork methods were participant observation and group discussions. Most of the latter occurred in connection with community-based education projects rather than the more common focus groups, although the two have a lot in common, both being centred round specific, pre-selected topics. One major difference is that in focus groups it is the facilitator/researcher who selects the topics, while in these education projects it was the participants who did so, based on their identification of the problems facing them. Here also the long-term relationships among group members as well as between them and the facilitators, tended to create high levels of trust, which positively influenced the opinions group members felt able to express. Thirdly, the discussions took place in multiple small groups of five or six persons each, the role of the facilitators being to move among the groups, asking pertinent questions to encourage sharper thinking at appropriate moments. ${ }^{6}$ These practices were based on the application of discovery-

Sense of Collectivity: Ethnicity, Nationalism and Globalisation, London: Pluto 2002, 3387.

5 For more information on the Religion and Society projects see the website www.uea.ac.uk/dev/kaduna.

6 For more detailed explanations of these processes see, Colette Harris, 'Transformative Education in Violent Contexts: Working with Muslim and Christian Youth in Kaduna, Nigeria' in IDS Bulletin, Researching Violence 40:3 (2009), 34-40; Colette Harris 'Deconstructing Masculinities in Kaduna, Nigeria', in Alp Biricik and Jeff Hearn (eds.), 
based pedagogies that supported participants to reveal the underlying issues, make their own analyses and apply their own solutions. ${ }^{7}$

My role in the education projects was to train local facilitators and participate in a few of the sessions; most of these, however, were carried out in my absence by the facilitators, who also made notes on the discussions. These notes and the ones I took myself form an important part of the data, all this of course subject to the same level of ethical scrutiny as in any other research project. In relation to the validity of data collected by this means, as always when using group discussions for research purposes, it is important to take inter-personal dynamics and the influences participants exert on one another into consideration, as well as the positionality of the facilitators. However, the fact that here the discussions took place mainly within small groups, to which the facilitators were largely peripheral, should have diminished the influence of facilitators/researchers over what was said.

The participants in the Kaduna projects consisted of women's and youth groups from different parts of the city, involving Muslims and Christians from a variety of denominations and ethnicities. The vast majority of participating youths were male but a handful of unmarried young women also joined in. While the women's groups embraced members of both religions, at the start Christian and Muslim youth groups worked separately; it was only later they started to collaborate.

\section{Trajectory of the Paper}

The paper starts by outlining my conceptual framework before going on to discuss how the main notions from it relate to the Nigerian context. Next, I describe the attitudes of both state and religious institutions in the wake of the establishment of new denominations that speak to the needs of contemporary society. I end by describing the situation in Kaduna,

\footnotetext{
Proceedings from GEXcel Theme 9: Gendered Sexualed Transnationalisations, Deconstructing the Dominant: Transforming men, 'centres' and knowledge/policy/practice Spring 2011, GEXcel Work in Progress Report XV (2011), 241252, accessed 1 August 2012, http://www.genderexcel.org/?q=webfm send/84. See also, Colette Harris, 'Working with Young Christian and Muslim Men on CommunityBased Pedagogies for Violence Reduction and Social Change in Kaduna, Nigeria' in Linda Woodhead (ed.), How to Research Religion: Putting Methods Into Practice, Oxford: Oxford University Press forthcoming 2013.

7 Following Paulo Freire, Pedagogy of the Oppressed, New York: Continuum International, Myra Bergman Ramos (trans.), (30th Anniversary Edition) 2005. See also Colette Harris, Pedagogy for Development: Some Reflections on Method, IDS Working Paper (2007), 289.
} 
analysing how some of its poorer male inhabitants make use of religion to help them cope with today's difficult and unstable economic situation, and the relationship with masculinities and violence.

\section{The Meaning of Gender}

Gender is simultaneously an effect of psychological development from infancy ${ }^{8}$ and a set of social practices, differing among cultural groupings but in today's world also affected by national and global influences. At the individual level it thus exists on both immanent and transcendental planes, meaning not all aspects are accessible to the consciousness and so available to be deliberately changed. Viewed from the sociopolitical level, gender is about hierarchical power relations imposed through locally applied sets of norms on differentially sexed bodies. Such norms fast become institutionalized and sedimented into tradition, to the point that certain elements within them come to look essential to human survival and appear eternal, the memory of even recent introduction lost. ${ }^{9}$

To become intelligible, gender must be expressed through 'actions, gestures, speech' aimed at 'produc[ing] the effect of some true or abiding feminine [or masculine] essence or disposition' - that is, it must be performed. Individual performances are constrained by pressures to conform to the expectations of one's social group, resulting in the production and reproduction of regulatory relations of power. ${ }^{10}$ Masculinity and femininity are interdependent, the former's superior positionality rendering it particularly vulnerable since its appropriate performance depends on the complementary performance of femininity. This helps explain the intense efforts often exerted on women to force their compliance and means that masculinity can best be studied in relationship with femininity. ${ }^{11}$

Although masculinity is concerned with the normative expectations placed upon males it is not simply an attribute of men, just as femininity is not of women. However, anxieties are always linked to any tendency to

8 Kaja Silverman, Male Subjectivity at the Margins, New York: Routledge 1992.

9 Judith Butler, Gender Trouble: Feminism and the Subversion of Identity, New York: Routledge 1999, second edition; Judith Butler, Undoing Gender, London: Routledge 2004; Connell, Masculinities; Colette Harris, Control and Subversion: Gender Relations in Tajikistan, London: Pluto Press 2004, 15.

10 Judith Butler, 'Melancholy Gender/Refused Identification', in Maurice Berger, Brian Wallis, Simon Watson and Carrie Mae Weems (eds.), Constructing Masculinity, London: Routledge 1995, 21-36: 31-32. Butler, Gender Trouble.

11 Harris, Control and Subversion. 
swap these around, since it appears as a threat to the gender order. This is particularly evident in the case of men suspected of adopting behaviour considered feminine, most obviously in the case of male homosexuality, seen as coterminous with relinquishing the active and hence superior power of masculinity. ${ }^{12}$

Nevertheless, nobody ever completely succeeds in conforming to the norms; the ways in which performances deviate depend on the individuals concerned and vary over time, as indeed do the norms themselves, even if most variations in the latter are too small to be immediately apparent. The extent to which individuals get away with deviance unpunished depends on its nature, as well as on the social capital of those concerned. ${ }^{13}$

Since gender is culturally dependent, it is influenced by modalities such as religion and ethnicity, in multicultural settings producing the coexistence of different sets of norms that influence each other to a greater or lesser degree. However, it also differs among social groups within each culture, depending on class, education level and other modalities and is further influenced by material circumstances. ${ }^{14}$ Moreover, some men appear to have achieved a more dominant or hegemonic version of masculinity, one that demonstrates a superior level of performance and hereby creates a role model others may aspire to but that especially for the poorest and least educated men is unlikely ever to be realizable. ${ }^{15}$

\section{Gender in Nigeria}

The gender structure described above applies to cultural settings privileging power relations based around the biological distinction between sexed bodies. ${ }^{16}$ In this respect, at least for the Igbo and Yoruba peoples who form the majority ethnicities in southern Nigeria, it has been claimed that historically gender was not a meaningful category, since in both cases, albeit in somewhat different ways, power relations were structured around

\footnotetext{
${ }^{12}$ Connell, Masculinities.

13 Judith Butler, Bodies that Matter, on the Discursive Limits of "Sex", London: Routledge 1993; Butler, Undoing Gender; Harris, Control and Subversion.

${ }^{14}$ Cf. Connell, Masculinities; Robert Morrell, 'The Times of Change: Men and Masculinity in South Africa' in Robert Morrell (ed.) Changing Men in Southern Africa, London: Zed, 3-37.

15 Connell, Masculinities.

${ }^{16}$ Ibid.
} 
seniority not sex. ${ }^{17}$ Claims that age was of greater import than sex for power relations among the pre-Muslim Hausa, the main ethnic group in northern Nigeria, have also been made. ${ }^{18}$ In all three cases, it was the dual contact with the colonial state and with patriarchal religion in the form of Islam or Christianity that destabilized cultural norms, allowing men to assume new levels of dominance.

While the Hausa took over the ideal of female seclusion from their Fulani rulers along with conversion to 1 slam, ${ }^{19}$ those converting to Christianity were also confronted with notions of male superiority and learned that women's role was to act as helpmeets to their husbands. Mission schools prepared boys for entry to the civil service, girls for futures as wives and mothers. ${ }^{20}$ Over the course of the twentieth century, almost all the inhabitants of Nigeria converted to one or other of these two religions, ${ }^{21}$ thereby encouraging the development of gender power relations nationally.

Gender is of course not merely a black box of unequal power relations. The performances expected of men and women encompass both self-presentation ${ }^{22}$ and the specific roles seen as appropriate for one's particular sexed body and sociocultural group. The colonial state added a new dimension - the concept of men as wage-earners. Although women continued to carry out productive work, the ideal of the domesticated female became important in struggles over men's wages and was

17 Ifi Amadiume, Re-Inventing Africa: Matriarchy, Religion and Culture, London: Zed Books 1997; Nkiru Uwechia Nzegwu, 'Review: Chasing Shadows: The Misplaced Search for Matriarchy' in Canadian Journal of African Studies 32:3 (1998), 594-622; Oyèrónké Oyěwùmí, The Invention of Women: Making an African Sense of Western Gender Discourses, Minneapolis: University of Minnesota Press 1997.

18 Murray Last, 'Towards a Political History of Youth in Muslim Northern Nigeria, 17502000' in Jon Abbink and Ineke van Kessel (eds.), Vanguard or Vandals: Youth, Politics and Conflict in Africa, Leiden: Brill 2005, 37-54; Frank A. Salamone 'Hausa Concepts of Masculinity and the "Yan Daudu"' in Journal of Men, Masculinities and Spirituality 1:1 (2007), 45-54.

19 Salamone, 'Hausa Concepts'.

20 Modupe Labode, 'From Heathen Kraal to Christian Home: Anglican Mission Education and African Christian Girls, 1850-1900' in Fiona Bowie, Deborah Kirkwood and Shirley Ardener (eds.), Women and Missions: Past and Present, Providence: Berg 1993, 126144.

${ }^{21}$ The Pew Forum, Tolerance and Tension: Islam and Christianity in Sub-Saharan Africa, Washington, D.C.: The Pew Forum on Religion \& Public Life 2010, 20, accessed 1 August 2012, http://pewforum.org/uploadedFiles/Topics/Belief and Practices/sub-saharanafrica-full-report.pdf.

22 Butler, Gender Trouble. 
eventually institutionalized, even if it never actually matched reality, especially in the south. Among the Yoruba, for instance, women have continued to play a significant role in productive activities. ${ }^{23}$ Nevertheless, new dimensions were added to local notions of personhood and today the male breadwinner norm is widely accepted in Nigeria to the point that it has become a dominant element within gender ideology. Even though in practice it may be impossible to realize and some women may in fact earn more than their husbands, ${ }^{24}$ this still puts a burden on men, who are expected to live up to it and are seen as failures if they do not.

In fact, the majority of men have not found it easy to do this, since few have ever been able to acquire steady employment that paid a living wage. ${ }^{25}$ During the first few decades after independence, decent employment was becoming easier to find. However, in the mid-1980s, when the international financial institutions forced the state to carry out structural adjustment, this process went into reverse as jobs disappeared and even many skilled men found themselves relegated to low-paid unskilled or semi-skilled employment, or with little choice but to enter the informal labour market. ${ }^{26}$ This is the situation in much of Nigeria today and certainly in Kaduna.

Therefore, the forces of globalizing capitalism that during colonial times helped produce the breadwinner norm have also been complicit in dismantling the structures that could have made it a reality. The result is the uneasy co-existence of a masculine cultural ideal lacking the material underpinnings that produced it, in a cultural setting in which the defining element of adult masculinity, the ability to exert effective control over wives and children, has also long depended on control over resources. ${ }^{27}$

${ }^{23}$ Lisa A. Lindsay, "Working with Gender: The Emergence of the "Male Breadwinner" in Colonial Southwestern Nigeria' in Catherine M. Cole, Takyiwaa Manuh, and Stephan F. Miescher (eds.), Africa After Gender? Bloomington, IN: Indiana University Press 2007, 241-252.

24 Andrea Cornwall, 'To be a Man' is More than a Day's Work: Shifting Ideals of Masculinity in Ado-Ado, Southwestern Nigeria' in Lisa A. Lindsay and Stephan F. Miescher (eds.), Men and Masculinities in Modem Africa, Portsmouth, NH: Heinemann 2003, 230-248.

25 Lindsay, 'Working with Gender'. See also Margrethe Silberschmidt, 'Women Forget that Men are the Masters': Gender Antagonism and Socio-Economic Change in Kisii District, Kenya, Uppsala: Nordiska Afrikainstitutet 1999.

${ }^{26}$ Toyin Falola and Matthew M. Heaton, A History of Nigeria, Cambridge: Cambridge University Press 2008.

27 See Margrethe Silberschmidt, 'Disempowerment of Men in Urban and Rural East Africa: Implications for Male Identity and Sexual Behavior' in World Development 29:4 (2001), 657-671; Colette Harris, 'Gender-age Systems and Social Change: A Haugaardian Power 
The consequences have been very negative, as both individuals and the state struggle to come to terms with the situation, some doing so by espousing what Connell has termed 'masculine fundamentalism', that is, the 'reaffirm[ation of] local gender hierarchies.' ${ }^{28}$

\section{Preserving the Gender Order}

Since 1999, when democracy was reinstated in Nigeria after a long period of military rule, both federal and state governments, unable or unwilling to deal with the high levels of corruption and other root causes of social and economic malaise, have used the ploy of redefining the issues along completely different lines to enable them to provide manageable solutions. ${ }^{29}$ Presumably, they hoped to reassure the population that in this way chaos could be kept at bay. They have done this largely by directing public attention towards the two institutions of public order that are the focus of this paper - religion and gender - in the apparent belief that this sleight of hand would remove from view the lack of infrastructure needed to facilitate economic development and the poor condition of public services that together have facilitated recurring episodes of violence.

This tactic was first used in northern Nigeria when Muslim majority states, including Kaduna, established shari'a law within their penal codes. They were encouraged to do so by overwhelming Muslim approbation, even if in places with large Christian populations, such as Kaduna, this also caused major unrest, and even occasioned major riots, as will be explained below. What the people hoped to achieve by this was to restore their own ideas of moral order - they believed shari'a law would compel the elites to put a halt to corruption and reduce inequalities by reinstating the Islamic institution of zakat or charity. In reality, the new legal code has been applied almost solely against the underprivileged, especially against poor women who appear to have transgressed the gender order. ${ }^{30}$

More recently, attempts have been made to regulate this order through legislation, with the federal government instituting procedures to banish gender deviance by 'prohibition[s] [that] protect ... society from the usurpation of its right to moral health and cultural decency.' The desire to do this was so strong that in 2008 a bill was introduced in the federal

Analysis based on Research from Northern Uganda' in Journal of Political Power, 5:3 2012.

${ }^{28}$ Connell, Globalization, 83.

${ }^{29}$ Cf. Wendy Hollway and Tony Jefferson, 'The Risk Society in an Age of Anxiety: Situating Fear of Crime' in The British Journal of Sociology, 48:2 (1997), 255-266: 265.

30 Ruth Marshall, Political Spiritualities: The Pentecostal Revolution in Nigeria, Chicago: University of Chicago Press 2009, 231ff. 
senate to criminalize 'sexual intimidation' and 'nudity', the latter defined as 'the exposure of any private part of [a woman's] body', including parts routinely exposed by traditional rural dress. Sexual intimidation refers to women using what is often their sole means of achieving advancement that is, the provision of sexual favours to attain employment or promotion. There is no provision for punishing men who benefit from this practice nor for enforcing gender equality in workplace practices, suggesting that one aim was to reduce women's ability to compete with men in this domain. ${ }^{31}$

While the bill never became law, its presentation and the fact it went through at least two readings strongly suggest members of congress wished to hold women responsible for the loss of social order. The moral side of the agenda was emphasized by the way the 'nudity' bill intended to incorporate 'religious bodies [to work alongside the government] in the reformation of the society for moral uprightness', a step that received enthusiastic support from the more conservative of such institutions. The largest Pentecostal Church in Nigeria, the Redeemed Christian Church of God, was one of the movers of this bill and clearly expected to play a significant role in enforcing it. ${ }^{32}$ The bill represented a significant attempt to reduce women's power position and thereby promote masculine superiority.

Even more draconian measures were introduced in 2011 in the shape of an anti-homosexuality bill, which this time did pass into law with the enthusiastic approbation even of some mainstream churches and mosques. It includes the provision of up to 14 years imprisonment for anyone convicted of engaging in homosexual acts; anyone proved to have been aware of such relations without reporting them may also become liable for long-term imprisonment. In northern shari'a states, Muslim men found guilty of practising homosexuality can theoretically receive the death penalty. ${ }^{33}$ Here we have yet another attempt by the government to promote their notions of traditional Nigerian masculinity.

Through casting the blame for their own failings and the country's economic woes on inappropriate gender performances, governments at

${ }^{31}$ Bibi Bakare-Yusuf, 'Nudity and Morality: Legislating Women's Bodies and Dress in Nigeria' in Sylvia Tamale (ed.), African Sexualities: A Reader, Oxford: Pambazuka Press 2011, 116-129: 118.

32 Ibid., 118.

33 Matthew Cortina, 'Nigeria's Anti-Homosexual Laws Also Apply to Tourists, Says Gov't' in The Christian Post, Africa (13 December, 2011), accessed 1 August 2012, http://www.christianpost.com/news/nigerias-anti-homosexual-laws-also-apply-totourists-says-govt-64738/\#Bo5a1jo21lfESfX6.99. 
both state and federal level have been drawing public attention away from their own failings by identifying scapegoats, labelling them as deviants, and simultaneously establishing measures to keep them under control, thereby giving the impression of having restored some kind of order. ${ }^{34}$ These pieces of legislation not only promote the idea that preserving a repressive form of gender order is an important part of state policy but also that religious institutions as well as individuals have a duty to support the government in enforcing this. The weight the Nigerian state gives to it can be measured by their open defiance of the western world, after Britain, the United States, and other governments not only strongly opposed the 2011 antihomosexuality bill but also threatened to remove aid streams when the Nigerians refused to back down. ${ }^{35}$

\section{Religion, Masculinities, and Order in Nigeria}

Nigeria's gender order has thus been institutionalized through both the state and religious establishments. In fact, as Eisenstadt suggests, the production and maintenance of order more generally is central to the whole notion of religion, that is to the '[construction of] a realm of the sacred, in which direct contact with the roots of cosmic or social order is established, and which serves as a focal point for the construction of symbolic and institutional boundaries inherent in the constitution of such order. ${ }^{36}$ He goes on to say each religion has its own organisatory codes, which also serve to bind its members together. These are linked to local cultural ideals, among which is the appropriate performance of gender. ${ }^{37}$

I hesitate to apply the term religion, filled as it is with Europeanized, Christian-based ideology, to traditional African rituals. ${ }^{38}$ Since these are concerned with appeasing the spirits and asking their support for human endeavours, however, they fulfil a similar function to religion in their

34 Using a similar approach to the one the British government adopted in relation to crime. See Hollway and Jefferson, 'The Risk Society'. Or that the US government used in suggesting it was welfare paid to single mothers that was bankrupting the state (accessed 1 August 2012, http://www.huppi.com/kangaroo/L-runawaywelfare.htm). Ola Awoniyi, 'Nigeria Pushes Ahead with Anti-Gay Bill Despite US Moves', Agence France Presse (7 December 2011), accessed 1 August 2012, http://www.google.com/hostednews/afp/article/ALeqM5hGMOBMHXSWgpF2LnZ8P37 9ocgQAw?docld=CNG.031c6610f1165094d5d5eea3e35a3113.61.

36 Eisenstadt, 'The Construction of Collective Identities', 34-36.

37 Ibid., 39.

${ }^{38}$ See Bryan S. Turner, Religion and the Modern Society: Citizenship, Secularization and the State, Cambridge, Cambridge University Press 2011. 
concern with keeping chaos at bay. ${ }^{39}$ In fact, religious conversion has often been less about abandoning traditional rituals than adding powerful new spirits to existing ones, ${ }^{40}$ so it is not uncommon even today for churchgoers to continue their traditional rituals. ${ }^{41}$ Yoruba carry out Ogboni rites while Bori (spirit possession) cults are practised by Hausa Muslims in northern Nigeria. ${ }^{42}$ It is said that traditional rituals took on particular salience as a consequence of colonially produced instabilities. The latter have been significantly increased by structural adjustment, which may well go some way to account for the global growth in religiosity since the domination of the world by neoliberal ideology.

The stresses of the last few decades have shown the inability of mainstream churches and older forms of Islam to provide the level of order, control and conviction many people are seeking to help hold back the demons of chaos. As a result, clerics from mainstream churches say they have fast been losing membership to reformist versions of Islam and charismatic Christianity and this has created considerable bad feeling between the two groups. Nevertheless, these newer establishments are becoming increasingly attractive, particularly to the young seeking support unavailable elsewhere, ${ }^{43}$ with the concomitant legitimization of the current gender order playing a crucial role in a further manifestation of Connell's masculine fundamentalism. ${ }^{44}$ In other words, in these institutions, gender regimes that promote masculine superiority go hand in hand with a tendency towards literalist interpretations of the scriptures, together producing a level of assurance missing in most other aspects of contemporary life.

This is accompanied by a tendency to treat other religions/denominations in a hostile manner aimed at producing strong collective identities, in part by each church or mosque drawing firm boundaries around themselves and their congregations, simultaneously

39 Okot p'Bitek, African Religions in Western Scholarship, Kampala: East African Literature Bureau 1970.

40 Stephen Ellis and Gerrie ter Haar, Worlds of Power: Religious Thought and Political Practice in Africa, London: Hurst \& Co. 2004.

${ }^{41}$ Colette Harris, 'Some Gender Implications of the Anglican Conversion of the Acholi People of Northern Uganda', Gender and History (forthcoming 2013).

42 Salamone, 'Hausa Concepts'; Toyin Falola and Ann Genova, Yoruba Identity and Power Politics, Rochester, NY: University of Rochester Press, 241.

43 Marshall, Political Spiritualities.

${ }^{44}$ See, Mark W. Muesse, 'Religious Machismo: Masculinity and Fundamentalism', in Stephen B. Boyd, Merle Longwood, and Mark Muesse (eds.), Redeeming Men: Religion and Masculinities, Louisville: Westminster John Knox 1996, 89-102. 
scapegoating and excluding the 'other', whether members of a different religion or of different branches of the same religion. This has served to enhance the certitude of the righteousness of one's own group, ${ }^{45}$ a process in which notions of appropriate gender performance occupy a central place.

This is certainly the case in northern Nigeria, where a plethora of new religious institutions has now sprung up, particularly noticeable on the Christian side, but visible within Islam too. While intra-religious conflicts among both Muslims and Christians used to predominate, so that even today Sunni and Shi'a, Catholic and Protestant, form uneasy bedfellows, many of these new establishments have institutionalized interreligious hostility, ${ }^{46}$ thereby facilitating the sectarian violence that has become rife in northern Nigeria over the last few decades.

A further trend is the totalizing of religious experiences in ways that close off all space for grass-roots activities or informal worship. The more conservative of the new denominations aspire to dominate all aspects of their congregations' lives and explicitly find ways to substitute for the kinds of practical and emotional support earlier gained through extramural activities, such as traditional African rituals. ${ }^{47}$ This is the case both for reformist Muslim sects, such as Yan Izala, which is very popular in Kaduna and the aim of which is to purify Islam of local accretions, ${ }^{48}$ and the charismatic Pentecostal churches in which healings and exorcisms are regular occurrences. ${ }^{49}$

\section{Men's Coping Strategies in Kaduna}

\section{Background ${ }^{50}$}

Kaduna was built as an independent capital for northern Nigeria shortly before the north and south were joined to form one country in 1914. During the succeeding decades, missionaries and their schools proliferated

${ }^{45}$ Marshall, Political Spiritualities.

46 Ibid.

47 Ibid.; see also Harris, 'Some Gender Implications'.

48 Ousmane Kane, Muslim Modernity in Postcolonial Nigeria: A Study of the Society for the Removal of Innovation and Reinstatement of Tradition, Leiden: Brill 2003.

49 Marshall, Political Spiritualities'.

50 For more details on Nigerian history, see Falola and Heaton, A History. For a history of Kaduna, see Colette Harris, 'Violence in a Religiously Divided City: Kaduna, Nigeria from the Shari'a Riots of 2000 to the Post-Election Riots of 2011', Space and Policy, 28:4 (forthcoming 2013). 
in the south but the British largely kept all such activity out of the north. ${ }^{51}$ As a result, by independence in 1960 the south had vastly higher education levels and with them a considerably superior economy. ${ }^{52}$ To offset this, one condition of independence was that the north would be accorded political leadership, in this way institutionalizing the north-south, Muslim-Christian split. ${ }^{53}$ Today this divide has become highly politically salient, producing numerous episodes of sectarian violence, ${ }^{54}$ while the south has continued to be better educated and more developed.

The Nigerian economy is now dominated by oil revenues. These were used by the post-independence developmental state to finance infrastructure, health services and schools. As oil prices rose in the 1970s, so did public spending, only to crash after 1982 when the world price of oil dropped dramatically, leaving the state unable to meet its financial commitments. In 1985 politicians succumbed to international pressures to implement World Bank and International Monetary Fund plans for a structural adjustment programme; this proved so disastrous the country has never recovered. Now exposed to the vagaries of global markets, the economic situation has been steadily worsening, producing high levels of unemployment, ${ }^{55}$ while political office holders gain access to oil revenues they are able to exploit for their personal benefit.

Kaduna sits in the middle belt, its population evenly divided between Christians and Muslims. The latter are mainly of Hausa ethnicity while the former consist of members of local tribes together with southern migrants, mainly Igbo and Yoruba, although a considerable proportion of the latter is Muslim. ${ }^{56}$ With unemployment rates well above the Nigerian average - over 20 per cent of adult males and a much higher percentage of youths have no steady work ${ }^{57}$ - the population's economic situation is problematic. The Hausa still suffer from a disparity in education levels with a very small percentage attaining post-secondary education and around

51 Marshall, Political Spiritualities, 116.

52 Helen Chapin Metz, 'Nigeria: a Country Study' in Martin P. Mathews (ed.), Nigeria: Current Issues and Historical Background, New York: Nova Science Publishers 2002, 81180.

53 Matthew Hassan Kukah, 'Christian-Muslim Relations in Sub-Saharan Africa: Problems and Prospects' in Islam and Christian-Muslim Relations, 18:2 (2007), 155-164.

54 Falola and Heaton, A History.

55 Ibid.

56 Falola and Genova, Yoruba Identity.

57 The Forum for Cities in Transition, City Profile: Kaduna [2011], accessed 1 August 2012, http://citiesintransition.net/page/city-profile-kaduna. 
half having no more than primary education. ${ }^{58}$ This leaves them considerably disadvantaged in regard to employability compared with the far better educated Christians.

Theoretically, they should be able to compensate for this through their social networks since the Hausa have long dominated political life in Kaduna. In practice, however, this works only for the minority with appropriate connections as well as at least some relevant qualifications or skills. Moreover, not only are their womenfolk very largely prohibited from taking up employment outside the home but, since Hausa men favour polygyny and often eschew birth control, they tend to have large families, making providing for them quite onerous.

Over the last few decades, a number of episodes of sectarian violence have occurred. The worst in terms of numbers affected took place in February 2000 over disagreements relating to the proposition that shari'a law be incorporated into the criminal code of Kaduna State, ${ }^{59}$ the latest was sparked off by disputes over the 2011 presidential election.

\section{Religion and Masculinities ${ }^{60}$}

The increasing economic destabilization of the last few decades has left the majority of the population of Kaduna struggling not only to make ends meet but even to fulfil social obligations. In particular, men's difficulties in achieving the male breadwinner norm have placed whole families in a problematic position so that people have been seeking help to cope with their difficult circumstances.

Meanwhile, little support is provided by secular organizations. While there are NGOs in Kaduna, the participants in our project have received little help from them or indeed from the government. The retreat of the state and the dearth of effective civil-society institutions have placed religious institutions in an advantageous position. The men I worked with indicated they regarded religion as a valued aid in warding off chaos, in relation to both its spiritual side and the provision of practical support offered by churches and mosques. The latter, for instance, do their best to provide financial assistance for their poorest members to help them cope with their overall situation and where necessary to meet medical and

58 The Pew Forum, Tolerance and Tension, 297.

59 HRW, The 'Miss World Riots': Continued Impunity for Killings in Kaduna, Human Rights Watch 15:13(A) (2003), accessed 1 August 2012,

http://www.hrw.org/sites/default/files/reports/nigeria0703 full.pdf.

60 Where not otherwise stated, the references in this section come from Marshall, Political Spiritualities (mainly in relation to Pentecostalism) and Kane, Muslim Modernities (mainly in relation to Yan Izala). 
funeral expenses as well, even if only those mosques that receive help from international sources or that have a sizeable population of wealthy members, like the central mosque in Kaduna, are able to garner the means to do this effectively. ${ }^{61}$

What has most strongly drawn people to religion and particularly to its newer forms - reformist Islam and charismatic Pentecostalism - has been the spiritual support they offer. The waves of sectarian violence experienced over the past few decades in Kaduna and the continued economic crisis have led to a loss of confidence in the old convictions. People have been experiencing a general sense of despair and a lack of belief in the future, accompanied by feelings of helplessness in the face of their inability to play an active role in controlling their fate or even to understand what is going on and why.

It is here that the newer churches and mosques step in by bringing their members fresh certainties largely absent from the mainstream, in relation both to the causes of the current situation and ways of dealing with them. In particular, what is on offer here is structures of symbolic discourses in which Satan occupies a crucial place in the proliferation of obstacles to salvation. For one's protection and ultimate redemption it is imperative to situate oneself on the side of God while determinedly renouncing all the doings of the devil. Exactly how this is to be accomplished depends on the religion and the institution concerned, each of which has its own path to salvation, facilitated through its particular notions of appropriate order and accompanying organisatory codes.

Much of the theological message of the charismatic churches has thus to do with promoting the idea that what has gone wrong is the (attempted) takeover by satanic forces. This then suggests the problems we are living through today have been caused by elements on the supernatural plane, that is, by demons under the command of the devil. Muslims are also enjoined to abjure Satan, on the basis of Qur'anic verses that suggest him as the cause of poverty and the enemy of true Muslims. ${ }^{62}$

61 World Bank, Nigeria: Voice of the Poor: Country Synthesis Report, World Development Report 2000/2001 [2001], 32, accessed 1 August 2012, http://siteresources.worldbank.org/INTPOVERTY/Resources/3356421124115102975/1555199-1124138866347/nigeria.pdf.

62 See for instance Sura Al-Baqarah 169 - 'follow not in the footsteps of Satan; surely, he is to you an open enemy', Hadrat Mirza Tahir Ahmad, The holy Qur'an: Arabic Text and English Translation, Tilford, Surrey: Islam International Publications, Maulawi Sher 'Ali (trans.), 2004, 26. 
In both cases allegations of demonization are frequently made against the other religion.

Vital for both religions is adherence to appropriate gender performances. These are among the most important of organisatory codes and especially emphasized by the newer churches and mosques that as a general tendency support certain conservative elements, particularly male superiority, while shifting others, for instance to allow women access to aspects of public life hitherto closed to them.

For Muslims this means that, contrary to some notions of Hausa masculinity, men are expected to permit their womenfolk to attend school, especially the religious schools run by their own sects. Women are to be encouraged to study on the grounds that this is fundamental to the whole concept of Islam and the importance it places on learning and knowledge. However, this does not mean they should participate in public life equally with men. Having women in positions of political power is abhorrent to reformist Muslims, and indeed charismatic Christians do not promote women to the top power positions either.

The newer churches and mosques place considerable emphasis on dress codes. The issue of appropriate self-presentation raised in the 'nudity' bill is particularly significant for the more conservative of these establishments, which tend to espouse strict dress rules. For Christian women this entails wearing modest skirts and blouses, and eschewing trousers, jewellery, make-up and ornate hairdos. For the Muslims it has meant that over the last couple of decades, ${ }^{63}$ a cloak covering both head and body has become so much a mark of Hausa culture it is now worn by all in Kaduna but the most educated women and girls, irrespective of sect. Today, some have adopted an even more radical dress code whereby face, feet, and hands are also covered, leaving only the eyes exposed to view. For both religions, the wearing of such garments represents the display of appropriate femininity as symbolic submission to the will of God/Allah as well as to earthly masculine power.

Men are supposed to dress appropriately too. For Muslims, this means wearing northern Nigerian robes and covering their heads with a cap or a turban. For Christians, it means dressing respectfully, such as in a suit and tie. However, each denomination has its own regulations and there have been clashes within the Pentecostal Fellowship of Nigeria over

63 In the mid-1980s, Christian and Muslim women dressed alike, see Catherine Coles, 'Hausa Women's Work in a Declining Urban Economy: Kaduna, Nigeria, 1980-1985' in Catherine Coles and Beverley Mack (eds.), Hausa Women in the Twentieth Century, Madison, WI: The University of Wisconsin Press 1991, 163-191. 
exactly what these should be. Similar clashes have taken place among Muslim sects.

The charismatic churches and reformist mosques promote a rupture with the past that entails the rejection of former lifestyles and associated close ties, in some cases even including abandoning extended family relationships in favour of members taking the congregation of believers as their family. New gender practices are at the heart of the personal transformations required.

Both sets of establishments have proposed their own approaches to marriage. The main changes are in respect of polygyny and the payment of bridewealth. Efforts to eliminate these were at the centre of the attempts of early missionaries to re-engineer African gender norms, but they proved too deeply engrained in local cultures. ${ }^{64}$ Some African churches have even legitimized polygyny. The newer Pentecostals, however, insist on removing all such accretions in much the same way as does Yan Izala.

As a result, attempts have been made to stop or limit the payments that usually accompany weddings in Kaduna. These include not only bridewealth but multiple other sums paid to officiating clergy, to local officials and to various members of the bride's family. Removing these makes it easier for young men to afford to marry, an essential step in the attainment of adult masculinity and already difficult enough to achieve without additional payments, considering the need to provide an independent home and meet the concomitant expenses. This thus facilitates both their transition to adult manhood and their fathers' appropriate performance of masculinity (see below).

The charismatic Pentecostal churches are adamant no member of their congregation should practise polygyny. For obvious reasons this is not so clear-cut in respect of reformist Islamic sects, although there is a tendency there too towards the practice, if not the ideology, of monogamy. For some people there is a question mark over whether the Qur'an really legitimizes polygyny at will or whether this was rather intended to be a means of providing support to widows and orphans after a major disaster such as war. Moreover, the Qur'anic exhortation to treat all wives equally is considered impossible to comply with, so the suggestion is that the intention was to make monogamy the preferred mode of marriage in Islam. ${ }^{65}$ In Kaduna it is more local tradition, therefore, than religious sanction that has encouraged polygyny.

64 Compare, Harris, 'Some Gender Implications.'

65 Abdel R. Omran, Family Planning in Islam, London: Routledge 1992. 
The Muslims regarded this issue with ambivalence. On the one hand, it enhanced masculine status, on the other it demanded significant resources. Older men among the poorer inhabitants of Kaduna seemed to have favoured it and indeed some justified this by claiming it was mandated by their religion. However, the youths in our education project considered it made no sense for them to practise it and believed it would be unfeasible for most men in their generation to do so.

As suggested above, men see the difficulty of living up to expectations as breadwinner as the single most problematic aspect of contemporary masculinity in Kaduna, as also perhaps in Africa as a whole. It is experienced as a serious threat to their dispositional power position that is, the power that adheres to them through their positioning as adult men. ${ }^{66}$ In southern Nigeria, many men who have been unable to maintain this role themselves have had to see their wives take over as primary earners. ${ }^{67}$ This occurs much less in northern Nigeria owing to the Hausa practice of female seclusion, which to a certain extent has influenced Christian behaviour there too. While Christian women are not actually secluded and in Kaduna many of them go out to work, quite a few complained they were kept under stricter control than is usual among southerners, their husbands copying their Muslim neighbours in this respect. However, this not only puts greater pressure on men but is highly problematic for those unable to provide adequately. The inability of men of both religions to meet their wives' demands, suggests that even if the women do not earn more than their husbands like those Cornwall studied in the south west, this has still affected their level of respect for the men. Women have told me they often act aggressively towards husbands who fail to meet their expectations, to the point of provoking arguments that at times end up in violence.

The women appeared to feel that if they carried out their own child-rearing and domestic responsibilities appropriately, their husbands should fulfil their part of the 'patriarchal bargain' ${ }^{68}$ In a meeting of a men's group from one of the local churches, it was suggested that the women's expectations in effect demanded their husbands perform like 'heroes', so difficult were the men finding it to earn sufficient to give their families a decent standard of living.

Men's relationships with their sons were similarly fraught with problems resulting from economic hardships. Through their inability to

\footnotetext{
${ }^{66}$ Colette Harris, 'Gender-age Systems'; Silberschmidt, Women Forget.

67 Andrea Cornwall, 'To be a Man'.

68 Salamone, 'Concepts of Masculinity', 51.
} 
provide school fees or help their sons enter tertiary education, many men felt they were losing their offspring's respect, and this was confirmed when the young men showed resentment of their fathers' demands on them. These would be, for instance, to help with farming or other timeconsuming tasks, with neither financial remuneration nor even in many cases what the youths regarded as suitable gratitude.

The hurt expressed by the older men at their sons' negative attitudes reflected among other things the loss of masculinity the inability to command their sons' unquestioning obedience represented. This was exacerbated by their feelings of failure when unable to live up to expectations of fatherhood by providing properly for their offspring. A particularly important element of mature manhood here is the ability to support a son to marry and establish his own household, since passage to full adulthood is symbolized by marriage and procreation. The men's incapacity to provide this represented a double failure - both to live up to the ideals of masculinity for their age group, and to support their sons to live up to theirs.

This lack of the respect from other family members that adult men have long seen as their entitlement seriously threatens the gender order. Men's ability to exert their authority over wives and children is crucial here. The fact that in the past this had a material basis in adult men's control over resources is both (tacitly) acknowledged and simultaneously experienced as problematic now they are losing their grip on it. Even so, they still feel their dispositional power position entitles them to receive the same level of respect as before. The same phenomenon has been noted elsewhere in Africa, in northern Uganda ${ }^{69}$ and western Kenya, ${ }^{70}$ for instance. ${ }^{71}$ The problem is how to preserve this today when the material circumstances no longer warrant it. Here religion comes to the rescue, at least in part.

In Kaduna, the newer churches and mosques are particularly insistent on preserving male control over women. The latter have more of a role to play within the newer churches and mosques than in the mainstream ones but they are also expected to acknowledge their position as submissive and subordinate partners to their husbands. Such religious affiliation can therefore protect men from challenges to their power position, at least on the part of their wives.

\footnotetext{
69 Harris, 'Gender-age Systems'.

70 Silberschmidt, Women Forget.

${ }^{71}$ And to a certain extent perhaps in the west as well?
} 
The situation with sons is less clear. The newer establishments tend to support young men's desire for independence from their fathers, particularly if this entails the youths' deciding to become members in defiance of parental disapproval. Such a move allows them to free themselves from the burden of filial obligations. It is less apparent how this works in families where fathers and sons are members of the same charismatic church or reformist mosque.

The elements of masculinity dealt with so far have primarily been concerned with men's relationships with wives and children. Their relationships with one another in public spaces call upon different aspects of gender performance. Here the certainties emanating from the newer religious institutions, especially the demonization of the other religion, play a significant role. Sermons from both sides call for jihad on the part of their congregation against the forces of Satan, often implicitly or at times even explicitly naming the other religion as the source of evil. Ruth Marshall quotes a Pentecostal pastor who makes a call to join in what might be classed as a Christian jihad - 'a battle' in which the weapons were to be 'militant, strategic and aggressive prayer' since it was 'a war' against 'invisible powers in high places'. ${ }^{72}$ The aim here is in part theological and in part a struggle against those powers that might prevent Pentecostals from capturing the Nigerian state and, along with this, preparing for salvation during the immanent second coming. In all of these, Islam is characterized as an important and demonic enemy, an obstacle preventing the triumphal victory of this brand of Christianity.

Both millenarian churches and mosques hold religious warfare to be sacred and their clergy are not always as sure as the pastor quoted above that this should remain at the level of prayer. The result can be seen in the multiple episodes of sectarian violence that have occurred in northern Nigeria over the last few decades, producing tens of thousands of deaths. ${ }^{73}$ Calls to participate in the violence have come from religious as well as secular leaders. It is noticeable that these have frequently occurred within sermons preached by clergy from both religions and in some places religious leaders have even been accused of taking leading roles in attacks on members of the other faith. ${ }^{74}$

72 Marshall, Political Spiritualities, 1.

73 John N. Paden, Muslim Civic cultures and conflict resolution: the challenge of democratic federalism in Nigeria, Washington: The Brookings Institution Press 2005.

74 For instance, killings of Muslims allegedly intiated by a pastor in Christian-majority Zonkwa in southern Kaduna State during the post-election violence of 19t April 2011 
This has meant that religious masculinity has in part come to be defined through men's willingness to support their own, if necessary through violence. This at least was how the young men I worked with in Kaduna experienced it. They felt they were expected to concur with the idea that a 'real man' is one who supports his religion, if necessary by laying down his life for it. While, they said, each religion supported its own norms of masculinity, such institutions as the ability to impose seclusion on their womenfolk differentiating Hausa Muslim men from their Christian counterparts, in regard to violence and sectarian conflict there was great similarity between the performances expected of adherents of the two religions.

The performance of violence has even come to be constitutive of a certain kind of brotherhood, especially for those young men with few other ways of living up to local notions of masculinity. The major episodes in which large numbers of killings take place are the most vicious but they represent only a fraction of the multiple incidences of violence that have been occurring in Kaduna on a daily basis, aligning groups of youths from each religion against each other usually over trivial issues such as minor traffic accidents.

Thus, all too often in recent years, the togetherness of men in relation to church or mosque has occurred in responding to calls to violence. Churches have men's groups that meet regularly to discuss issues that concern them and this may well include family-related problems, and especially men's overwhelming preoccupation with earning a living, as I have indicated above. However, especially since the shari'a riots of 2000, the issue of violence all too often dominates people's thinking, especially recently, since fears of the 'other' have been reinforced both by the postelection clashes of April 2011 and by the escalating attacks on Christians on the part of the Islamic grouping known as Boko Haram.

Of course, men face many of the same quandaries in other parts of Africa too, as indeed in much of the rest of the world, since few places today are free of the destabilizing influence of the global political economy. The consequence has very often been intensified competition over resources, resulting in attempts to police the boundaries of moral communities in ways that facilitate exclusion and violence, similarly to what has been occurring in northern Nigeria. ${ }^{75}$ However, this region is

(accessed 1 August 2012, http://www.slideshare.net/Abumuslim2112/zonkwamassacre).

75 Jean and John L. Comaroff, 'Naturing the Nation: Aliens, Apocalypse, and the Postcolonial State' in Social Identities 7: 2 (2001), 233-265: 237. 
unique in Sub-Saharan Africa in certain aspects of its social relationships, first in its promotion of female seclusion and the wider influences this exerts on local society, but also in the politicization of religion and the way sectarian violence has come to dominate interpersonal relationships and everyday practices. Therefore, while as in other parts of Nigeria ${ }^{76}$ and elsewhere too, ${ }^{77}$ men in Kaduna spend the majority of their time trying to live up to their provider roles, many of their most serious concerns, in as well as out of the religious context, revolve around sectarian problems, especially the likelihood of a new outbreak, and the ways they will be called upon to respond.

\section{Conclusion}

Neither of the two dominant issues in Kaduna today - sectarian violence and unemployment - can be separated from religion. This is particularly true for male members of reformist Islamic sects and charismatic Pentecostal churches for whom besides material support, their creed has provided new ways of being in the world that have allowed them to cope spiritually with the precarious situations in which they find themselves. In part this has been attained through the moral support that has enabled them to maintain control over their families, despite their material problems.

Meanwhile, it is a paradox of today's situation that while the instability that plagues the population has partly been produced by sectarian violence, the newer religious institutions have tended to intensify the divisions between them, thereby effectively increasing the probability of further episodes of violence and so producing a vicious spiral.

These problems were facilitated by the way colonialism was implemented in Nigeria, along with the introduction of the two major religions that produced much of the gender power imbalance noted above. The combination legitimized breadwinning as a significant element within masculine normativity, while already during colonial times but even more because of the way post-colonial Nigeria has been embedded in the global political economy since then, the majority of its male inhabitants, and

76 E.g. Andrea Cornwall, 'To be a Man'.

77 E.g. Sylvia Chant, 'Men in Crisis? Reflection on Masculinity, Work and Family in North West Costa Rica' in The European Journal of Development Research, 12:2 (2000), 199218; Robert and Penny Morrell, 'Men in/and Gender Equality: A Conversation from South Africa' in Andrea Cornwall, Jerker Edström and Alan Greig (eds.), Men and Development: Politicizing Masculinities, London: Zed 2011, 111-125; Silberschmidt, Women Forget. 
especially those in the north, have effectively been prevented from being able to live up to this norm. The continuing economic crises make it unlikely that in the near future this will change for the better, especially since the neoliberal ideology imposed by the international financial institutions has rolled back the state and thus prevented its coming to the aid of the populace.

In effect, for large swathes of the population all options other than religion that might have provided either moral or material support have been eliminated, and this has facilitated the growth of the newer establishments as well as their competition over the state and the concomitant sectarian violence. On the positive side, this is also linked to notions of masculine brotherhood within church and mosque, albeit often played out in conflict situations. In this way, religion and masculinities have come together in men's struggles to survive in the complex situation of Kaduna today. 